\title{
ESP Practitioner Professionalization through Apprenticeship of Practice: the Case of Two Iranian ESP Practitioners
}

\author{
Batoul Ghanbari (Corresponding author) \\ PhD Candidate in ELT (English Language Teaching), Department of English, Faculty of Foreign Languages \\ University of Isfahan, Hezar Jerib St., P.O. Box: 8174673441, Isfahan, Iran \\ Tel: 98-917-775-3178Ｅ-mail: btghanbari@gmail.com
}

\begin{abstract}
Abbas Eslami Rasekh
Assistant Professor in ELT (English Language Teaching), Department of English, Faculty of Foreign Languages

University of Isfahan, Hezar Jerib St., P.O. Box: 8174673441, Isfahan, Iran

E-mail: abbasseslamirasekh@yahoo.com
\end{abstract}

Received: July 25, 2011

Accepted: October 10, 2011

Published: February 1, 2012

doi:10.5539/elt.v5n2p112

URL: http://dx.doi.org/10.5539/elt.v5n2p112

\begin{abstract}
English for specific purposes (ESP), the popular catchphrase of presently English language teaching programs, has been investigated from different perspectives. However, there have been occasional forays in to the role of ESP practitioner as one of the most distinctive features in the literature. In addition to fulfilling the usual role of a language teacher, ESP practitioner may be required to deal with administrative, personnel, cross-cultural, interdisciplinary, curricular, and pedagogical issues that may be unfamiliar to general English teachers (Hutchinson \& Waters 1990; Koh 1988; Robinson 1991; Waters 1994). Consequently, those practitioners who have passed the thorny way of professionalization would be great assets for the teachers who are new to the ESP programs. Moreover, lack of an independent disciplinary status for ESP worsens the issue. Drawing on the interview data and observational evidence, present study investigates the route of professionalization of two Iranian ESP teachers in the particular context of Petroleum University of Technology (PUT) in Ahwaz. What they say are critically analyzed in the context and emerging guidelines are categorized accordingly. It is hoped that findings grounded minimally in this particular ESP context will act as broad guidelines that bestow a more academic image to the general English teacher-ESP teacher change in the present 'no man land' of Iranian ESP teaching programs.
\end{abstract}

Keywords: ESP, ESP practitioner, General English teacher, EFL context, ESP teacher education

\section{Introduction}

English, the lingua-franca of almost all professional and academic settings, has come out in EFL/ESL circles as the English for specific purposes (ESP). A significant aspect of language instruction at a tertiary level is learning English for a given purpose, with the specific aims of getting to know specialized vocabulary, increasing one's knowledge of the subject matter by reading in English and being able to use the language in the prospective profession or study areas by becoming prepared for some common situations such as carrying out higher level studies, going for an interview or conducting professional correspondence (Varnosfadrani, 2009). Clearly, ESP teachers are required who are tactful and highly qualified in choosing contents, materials, methods, and mode of work, to enhance learners' automaticity and showing them the most effective ways of learning the language.

In the words of many scholars (e.g. Jackson, 1998), ESP teacher education has been among the many unresolved issues in ESP that have not been attended to adequately. The problem gets worse when considering the lack of a disciplinary status for the ESP. Presently, there are no ESP departments in Iran and the majority of ESP teachers are graduates of the ELT departments who have no initial preparation for their task of teaching ESP. The assumption in Iranian ESP programs is that language teacher is superior to the content teacher; therefore, general English language teachers are deemed as capable in handling ESP courses. Needless to say, novice teachers are faced with a complex network of issues and it is the teacher's job to find the right path of professionalization through a long process of actual practice.

The challenging situation that ESP teachers face and the several traits and skills that are perceived for success in 
teaching ESP such as flexibility, adaptability, creativity, resourcefulness, well developed organizational and managerial/leadership skills, effective interpersonal and cross-cultural communication skills, mature problem-solving and decision-making skills (Hutchinson \& Waters 1990; Jackson 1994,1995; Orr 1996; Robinson 1991), demand the researchers to seek for ways to seriously explore the route of ESP teacher professional development.

To achieve this goal, present study followed reality-based cases to enlighten some unknown aspects of ESP teaching practice. In this way, findings would provide guidelines for the beginner practitioners as ESP teacher education programs that are problem-based and practitioner-oriented can help student teachers develop the requisite skills and attributes through providing a kind of classroom apprenticeship for professional practice (Schon, 1983).

\section{Theoretical Background}

\subsection{Teacher Professional Development}

Generally speaking, professional development refers to the development of a person in his or her personal role (Eleonora, 2003). As an important trend in the growth and improvement of any educational institution, teacher professional development is a milestone in teachers' continuum of life-long learning and career progression. In this regard, many scholars have attempted to define teacher professional development in terms of a high-quality, meaningful and effective teacher enhancement.

According to Bolam (1993) teacher professional development refers to "any professional development activities engaged in by teachers which enhance their knowledge and skills and enable them to consider their attitudes and approaches to the education of children, with a view to improve the quality of the teaching and learning process." Regarding teachers' commitment, Glatthorn (1995) contends that teacher professional development is what a teacher attains as a result of experience and reflecting over his or her teaching systematically. Looking at external factors, Horsley (1996) views teacher professional development as "opportunities offered to educators to develop knowledge, skills, approaches and dispositions to improve their effectiveness in their classrooms and organizations."

Despite different approaches to the concept of teacher professional development, they all share the view that teacher professional development helps teachers master new skills, widen their knowledge, and develop an innovative insight into their pedagogy, their practice and their understanding of their own needs since a teacher's professional development is an aspect of his or her personal development as a whole.

Therefore, a developmental, integrative approach to teacher professional development views course room as having a rich life which unfolds over time, as events and processes interact, and shape the way participants think, feel and act. It emphasizes the situated nature of teaching and asserts the social construction of teacher identity (Singh \& Richards, 2006).

\subsection{Professional Development for ESP Teachers}

Teacher professional development is especially significant for teachers of ESP as their teaching career aims at developing the use of language skills in the subject matter areas such as Economics, Law, Telecommunications, Engineering, etc.

The main argument for the professional development of ESP practitioner is that propositions in ESP theory are not easily generalized to apply to specific teaching contexts (Dudley-Evans, 1997; Hutchinson \& Waters, 1987; Robinson, 1991). In fact, there is no espoused ESP curriculum that corresponds to the particular teaching setting that many a prospective ESP teacher may encounter. It is for teachers to develop their own curricula according to given learners' needs and to given teaching conditions.

In these circumstances, a set of ESP assumptions intended as a guide to practice might not actually serve the practical demands of a specific curriculum, which is to say that a conventional theory-into-practice ESP training model could seem insufficient without the context-specific principles of ESP curriculum development. Thus, prospective ESP practitioners among teachers of general English are justified in training themselves in a practice-into-theory direction by a process of professional reflection, problem-solving and decision-making (Maclean, 1997; Jackson, 1998). In this way, they may not only improve their practice but also learn to theorize about that practice, which process is the essence of ESP teacher professional development. In fact, in the words of Elliott (1991) through ESP teacher professionalization "theories are not validated independently and then applied to practice. They are validated through practice".

Therefore, the practice of professionalization in ESP requires drawing on real cases that bring the world of ESP practitioner into the classroom and help student teachers vicariously experience the problems and challenges involved in the sometimes messy world of ESP (Jackson, 1998, p. 152). 


\subsection{Benefits of ESP Professionals for Novice ESP Practitioners}

Jackson (1998, p. 154) enumerates the benefits of analyzing expertise for novice ESP practitioners. She believes that through the process of analyzing reality-based experiences in any ESP teacher education program, prospective teachers can:

- enhance their overall communication skills: the ability to listen critically and empathetically; read for detail, make inferences, synthesize information, and express ideas orally and in written form in a more clear, confident, and convincing manner (Asbaugh \& Kasten 1995; Merseth 1991a, 1991b);

- refine their interpersonal and teamwork skills: learn how to cope with emotions and conflict more professionally; discover first-hand how ESP practitioners benefit from consultation and collaboration with other ESP professionals as well as with colleagues from other discourse communities and cultures (Easton 1982; Jackson 1996a, 1996b);

- better understand and articulate their own values and beliefs: discover how to make decisions based on facts instead of relying on hidden assumptions and personal biases (Easton 1982; Merseth 1991a; Merseth \& Lacey 1993; Wassermann 1994a);

- view a dilemma through the eyes of different participants and predict the possible consequences of several outcomes (Merseth 1990; Wassermann 1994a, 1994b);

- sharpen their analytical, problem-solving, and decision-making skills: think more clearly and methodically in the often confusing, ill-defined situations of ESP practice where there are few clear right or wrong courses of action (Cooper 1995; Cossom 1991; Doyle 1990; Kleinfeld 1991; Merseth 1990,1991b);

- narrow the gap between theory and practice: learn to apply and adapt conceptual and theoretical knowledge to real world dilemmas in ESP practice (Asbaugh \& Kasten 1995; Hutchings 1993, 1995);

- develop effective leadership or managerial skills: students have the opportunity to take on the role of a teacher or leader as they express their views and encourage other group members to focus on the key issues in a case (Asbaugh \& Kasten 1995; Cooper 1995; Swales \& L'Estrange 1983);

- learn to think and react like professionals as they become socialized to the world of ESP practice (Asbaugh \& Kasten 1995; Feiman-Neimser 1990; Kleinfeld 1992; Schon 1987);

- become "reflective" ESP practitioners, that is, professionals who critically examine decisions and actions in their teaching situations on a regular basis (Richards 1991; Richards \& Lockhart 1994; Schon 1983; Weaver et al. 1994).

The above-mentioned benefits demonstrate how analysis of the hidden world of ESP professionals would offer advantages to novice ESP teachers. ESP teacher education programs can substantially draw on the experiences of ESP professionals who are aware of the intricacies of the field. Through providing practical insights, they would act as guiding models for the beginners to the field in a context where there are no established norms of the discipline.

\section{Research Question}

In line with the above arguments, present study was designed to answer the following research question:

What does the analysis of two Iranian ESP professionals 'practice offer to novice ESP practitioners?

\section{The study}

To achieve the ESP insiders' views in the route of professionalization, present study was launched to investigate the hands-on experiences of two Iranian ESP practitioners with a long experience of teaching ESP at Petroleum University of Technology (PUT) located in Ahwaz, southwestern of Iran. Following a narrative style, researchers conducted semi-structured interviews with the participants. The setting of the study was a typical ESP context in which English was taught for petroleum-related majors.

\section{Method}

\subsection{Participants}

Sha'ban Vardak and Mohsen Pourghaffar- the two experienced ESP teachers at PUT - participated in the present study. Vardak got his MA in English Language Teaching (ELT) from Shiraz University. He had taught ESP at PUT for 27 years. At the time of study, he was the head of English Department at PUT. The other participant, Pourghaffar, had an MA in ELT from Tehran University. He also had taught ESP for 25 years at PUT. Apparently, both of the teachers were highly experienced in teaching ESP. They had also experienced different times in the faculty when English status had serious fluctuations (Table 1).

\subsection{Setting}

The research context of the present study was Department of English at PUT located in Ahwaz. Ahwaz faculty of 
petroleum engineering is the most famous branch out of four branches of PUT. Department of English is very dynamic in teaching both general English and ESP. English as the only foreign language at PUT has a prominent position to the extent Department of Basic Sciences has incorporated it under its domain. The objective of ELT at PUT is to prepare prospective petroleum engineers to cope with subject knowledge involved in different aspects of the petroleum industry as well as function proficiently in everyday English.

English has had a fluctuating history at PUT. Before 1988, newcomers to the university were required to study just English for the whole first semester. It was about 24 hours a week. The English taught was general English. In case students passed these English courses in the first semester, they could start English 1 which included general English and Basic English for science. In the third semester, students began studying their specialized courses in English called Petroleum Program. It was the way English was treated until the year 1988. After this time, due to some national educational policy, the load of English at universities including PUT gradually decreased. Present situation in the university shows that English had only 10 credits, considerably a dramatic decrease. However, English is an obligatory course for all students in the first year of the faculty.

\subsection{Data Collection and Analysis}

In order to collect data for the present study, researchers developed a semi-structured interview (Table 2).The interview items were designed in a way that deliberately addressed some dilemmas teachers might have faced during their teaching practice at PUT. Overall, out of six interview sessions, three were done collectively with both of the participants and three individually with each. Moreover, researchers obtained the consent of both the teachers and the students to observe the classes and audio-record the lessons and use the data in the class. The teachers were informed of the general purpose of the study, that is, to investigate their classroom practice and cognitions, but they didn't know about the focus of the study as it might influence their class behavior. Critical points were recorded and discussed with the teachers in the interview sessions. Both interview sessions and observations were done systematically over the course of one full semester.

To analyze the data, qualitative content analysis was used. The common practice in this mode of analysis is to analyze the data to the extent that categories, themes and patterns emerge. Upon recording the interviews, they were transcribed verbatim and the researchers carefully read the transcripts multiple times. Considering the general themes followed in the interviews along with the background literature, the researcher classified the parts which were related conceptually. Later, these initial hunch-like classifications were refined and converged under the final four general categories.

\subsection{Procedure}

Researchers unveiled the world of ESP at PUT through interviews and observations. The interviews were designed in a way to reveal some of the hidden issues associated with ESP in this particular context. Some of the interview items were controversial; therefore, they asked for class observation to practically sense the class and the teachers' specific tact for dealing with in-class unique episodes.

The analysis of semi-structured interviews was carefully done. Following the common steps in any qualitative content analysis, researchers followed these broad steps to analyze the data: transcribing the data, pre-coding, coding, growing ideas and finally interpreting them and drawing conclusions in the form of themes (themes as concepts that explain how ideas and categories are related).Observations were documented by the researchers. They carefully audio-recorded the class scenarios they observed. In fact, these observation data acted as kind of triangulation over the interview results. The observation documents were analyzed in an inductive manner to seek for the patterns emerging from the data.

With regard to establishing trustworthiness as an essential element of conducting any type of qualitative research (Merriam, 1998), researchers began to seek for evidence regarding its four components of credibility, transferability, dependability and confirmability. The measures taken by the researcher to establish credibility of the study were: reviewing the transcripts with the colleagues, member checking and triangulation of data in order to enhance the findings and interpretations of the study. To show the degree of transferability of the present study, a thick description of the research context and participants was provided by the researchers, therefore paving the ground for other interested researchers to share the results of the study to other contexts and also replicate the study.

A comprehensive documentation of the research process and data collection procedures along with establishing inter-coder reliability was done to establish the dependability and confirmabilty of the study. So, in order to verify the consistency of the coding of the interview transcript, it was analyzed by some ESP practitioner who was an ELT graduate and also had experience in teaching ESP in different universities. Achieving Kappa value above .70 (SPSS 
19), showed that the two codings by the researcher and the assistant were substantially similar. It was a reliability check over the classifications to show that codings in this study are reliable and consistent.

\section{Results \& Discussion}

Present study was conducted in a search for the "how" of professionalization of two ESP teachers in a context where there was no formal ESP teacher education program. In fact, the impetus was to find some broad guidelines grounded in the very context of ESP teaching to aid the practitioners better overcome the hurdles faced with in their professional life. Any guidelines emerged from the actual practice of the practitioners would give prestige to a field largely ruled by the content teachers' idealizations and policies.

A comprehensive analysis of the elicited interview data of the two ESP teachers along with the patterns found in the observations showed the existence of four broad categories which are classified and elaborated upon below. Excerpts of the interviews and some snapshots of observations are brought as evidence. It should be mentioned that interviews were conducted in Persian (native language of the participants) and the excerpts are in fact translations to English.

\subsection{ESP Program as A Resource for Teachers' Limited Entrance Content Knowledge}

Remembering their initial days of teaching ESP at PUT English Department, both Vardak and Pourghaffar asserted that although they had a good command of English, they were not competent in teaching petroleum English.Vardak said that the practice of teaching ESP was to a great extent new to him. He had no prior knowledge about the petroleum English. He believed that his present knowledge was to a large extent due to the mere exposure. During the long time of teaching at PUT, he could attain a deep knowledge about petroleum English. He described those days of teaching as so:

"I was so eager to learn petroleum English. I studied not only course books but got other sources as well. I scribbled down whatever new words that I had to find a translation for the students in the class. Although it was a hard time and I was in a risky position of not knowing some new words or structures, but it really encouraged me to progress.At least it helped me not to lose my class management".

Pourghaffar, the other teacher, believed that he had also little formal knowledge regarding teaching petroleum English. Drawing on his story of teaching, he said:

"My father was a mechanic and I was aware of mechanical terminologies but little knowledge of the petroleum. I had no formal training in ESP and from the first days of teaching at PUT, I seriously studied related books. Standards of teaching in this university were high; therefore, I had to improve my knowledge of petroleum English. I asked content professors and consulted technical dictionaries a lot."

The hidden point in the words of the two participants was a strong belief in the potential capability of language teachers who have a good command of language when faced with content problems. Both of the interviewees said that they could gradually overcome their lack of content knowledge and could teach petroleum English to intelligent engineering students in a prestigious university like PUT. Interestingly, Pourghaffar explained his analysis of the phenomena:

"In my opinion, when you want to teach English for whatever content areas, you are dealing with language in the first place. That is, you have a general structure including slots such as noun, verb, object...The only thing you do is to fill these slots. So, language is the backbone of any ESP teaching".

The point for ESP practitioner is that he/she is a language teacher and finally is identified and judged as a language teacher. Therefore, despite a wide array of responsibilities deemed necessary for ESP teacher, this approach to ESP would increase self-confidence of novice teachers and help them to rephrase their "language of knowledge".

\subsection{Hierarchies of Practice}

In their descriptions of the first days of teaching at PUT English department, the teachers spoke of a multi-layered scenario. They called the first days as challenging and hard. Apparently, they sought survival in their classes. It was interesting that both teachers reported no behavior clashes in the classroom, but teacher credibility was loosely held in those days.

In fact, it was after many critical moments that both teachers could establish their authority and exert their norms of discipline in the class. Vardak described those days of crisis as so:

"In my early days of teaching at PUT, it was really hard and frightening. I had to study the textbook before going to the class. The students' view of English teacher teaching petroleum program was an authority not only in English but also in other subject areas such as mathematics, mechanics, chemistry..." 
In the same line, Pourghaffar disclosed some of those critical issues when he said:

"The problem was not just teacher's dominance over the content, but an array of issues was involved. You are a teacher and you should act in a way to organize diverse determining factors such as class management, effective strategy use, resourcefulness... All should target and aim for keeping the authority of the teacher in the ESP class"

Moreover, both participants believed that they had to be resourceful strategy user in the class (explained more in section 6.4. below) that dramatically helped them to survive at times. For example, Vardak explained one of the challenging episodes like:

"I did every effort to avoid problems occur in the class. The solution for me was to pinpoint some ready students who come to ask many questions, too. By experience, I usually anticipated the kind of questions they might ask and made myself ready by having in mind one or more courses of action to respond to their reactions and any probable problems".

Both teachers confirmed that they were experiencing stages of professional development through their teaching practice. Their assertions in the interview sessions clearly showed that they were progressing in the field. The care and stress of the early days were gradually replaced by the authority and independence of the teachers to the extent that they could easily analyze problematic moments and intuitively decide on the most appropriate courses of action.

In one of the observations of Vardak's classes, the issue of teacher authority was easily noticed. He asked students to collaborate in groups of three in the class. At other time, he assigned them to voluntarily give lectures or provide more explanations on a new concept they were taught that day. The students were advised to refer to the related courses such as geology to explore the concept in more depth. Such a mood of class management and referring learners to other strong content sources all pointed to the fact that teacher was in a powerful position.

As another example of gradual development in the field, Vardak said how he can impress his students by not saying the definition of any difficult word in its specific context but by explaining its diverse meanings in different related disciplines such as chemistry, mechanics...He attributed this present teaching state-which was in sharp contrast to the beginning days - to the expertise acquired through a lengthy process of professional development in ESP teaching.

In sum, as many scholars (Schon, 1983; Huberman, 2001) have counted different stages that novice teachers undergo in their practice, novice ESP practitioners should acknowledge the fluctuating route of their practice and through exploring professional experiences of the hierarchies of the practice related to each stage come to a balanced and committed authority in their profession. In case of the ESP practitioners in the present study, the move towards normalization in class routines occurred gradually. The experiential knowledge obtained over the time was to a large extent due to involvement with challenging dilemmas happened at different stages of teaching with different levels of complexity and managing to settle them down in the classroom.

Prior awareness of the stages of practice would substantially direct the efforts of the ESP practitioner in the class. In case practitioners be equipped with this "meta-knowledge", they will decide on the appropriate courses of actions in a more informed and helpful manner.

\subsection{A Collaborative ESP Curriculum Development}

Designing curriculum for petroleum engineering students was done in a collaborative manner. Interviewees said that at the beginning of their teaching at PUT, the selection of textbooks for different courses was solely done by the head of the Department. They talked about Dr.Ashkiani, then head of the department, who decided on the suitable textbooks for students in different petroleum-related majors. Pourghaffar said:

"Text-books were selected by Dr.Ashkiani. Mostly they were original. Our job was to teach them to see how effective they were. At the end of any semester, we argued on the appropriateness of the books in our group sessions".

Passage of time helped teachers to develop a good amount of knowledge on the suitable textbooks. Gradually, decision-making was transferred to the English group. Teachers and head of department consulted on the selection of the textbooks collectively. The selected textbook was taught to see how it worked in practice. The ones which were not practically useful were put aside and the search for the new ones began.

This helpful cycle of collaboration in the department offered great advantages to the curriculum development at PUT. Teachers were dynamically involved in need analysis, planning, implementation, evaluation and follow-up modification. The process helped them design the curriculum in a way that was of most benefit to the students.

6.4 ESP Teacher Develops Repertoire of Strategies in the Route of Professionalization

Hutchinson and Waters (1987, p. 158) describe ESP teachers as "reluctant dwellers in a strange and uncharted land", 
a land that Belcher (2006) also considers for many ESP teachers as intimidating. It goes without saying that general English teacher who steps on the difficult land of ESP teaching faces several obstacles which might even threaten his/her survival as a language teacher. Therefore, professional artistry (Schon, 1987) necessitates novice ESP teachers to draw on any resources to act effectively in the uncertain and perplexing situations of teaching. As an example, Furlong and Maynard (1995) when describing the third developmental stage that novice teachers go through explain how teachers face difficulties by establishing their authority as a teacher and also by developing teaching strategies.

Needless to say, strategies as specific informed solutions aid ESP professionals to address the unique teaching situations they face in an active, informed and reflective manner. Thus, exploring the repertoire of strategies that ESP professionals have developed over the course of their practice would be invaluable in paving the ground for more sophistication in ESP teacher development.

In addition, since strategies are specific solutions that teachers adopt to deal with unpredicted class dilemmas they become important as understanding teachers' cognitions will inform ESP teacher education programs. Two participating teachers in this study reported on different problematic episodes in their classes when they behaved strategically. They counted different strategies that they developed during the course of their practice. In their ideas, these strategies as developed in a specific social context and attested in an informed and critical manner were culturally appropriate and pedagogically sound. These strategies included a broad range of coping strategies which can be divided in to cognitive, meta-cognitive, behavioral, teaching-related and social strategies. Included in Table 3 are main coping strategies and the subcategories associated with each in this study.

In the following, three selected strategies along with an example of each are brought for a more thoughtful discussion. Interview excerpts including teachers' rationale are also mentioned to show how they acted to keep their face and also the smooth flow of teaching.

\subsubsection{Behavioral: Risk-taking Strategy}

From his first days of teaching, Pourghaffar remembered how he employed risk-taking strategy by getting students discuss with each other when anticipating the problems that threatened his face. He could easily draw the point from their discussions. Pourghaffar described his risk-taking strategy as so:

"Strong personal relations with students helped me to know bright students quite well; therefore, sometimes when I faced with problems I had no way but to elicit the response from them. Although it was risky, I think keeping the image of teacher as a knowledgeable person in the early days of teaching when students were forming their impression of the teachers was more important. Of course, for more confirmation, I later consulted the subject knowledge professors".

He continued to say "It occurred that I forgot to ask the subject teacher about some new terms. So, when translating I faced some new words that I didn't know the meaning. Actually, I had no way but to continue my translation. I had to save my face as a knowledgeable and respectable teacher in the class; otherwise, students lost their trust in me. I thought about different courses of action, for example literal translation, saying some close meaning or asking students as they might have learned the words in their subject classes. Many times, these particular tacts worked and I could manage the class in an effective way".

\subsubsection{Cognitive Strategies: Using Pedagogic Aids to Compensate for Teacher's Lack of Subject Knowledge}

In a sense, all teachers' strategies- as are reflections of the teacher's cognition for each class phenomenon - can be called cognitive strategies, but here this category of strategies refers minimally to those strategies that are confined to the teacher's use of pedagogic devices to resolve his lack of content knowledge. As examples in this category, Vardak commented that he frequently used technical dictionaries. Students were also required to bring dictionaries with themselves to the class.

He explained that:

"Most (and probably all) ESP teachers face in-class problematic situations. The occurrence of these unexpected situations does not necessarily reflect poorly on the teacher. In fact, there are many ways of tackling them.ESP teachers, related technical dictionaries and probably students are all in a way potential sources of information about subject specialism and its language”.

Both teachers urged learners to have dictionaries with themselves in the class. They were asked to search for different points such as the correct pronunciation or detailed nuances of meaning in the dictionaries.

Another pedagogic aid was setting an appropriate time frame for different class activities and the overall sequences of the class. Teachers found timing quite helpful since it would help them not to dwell on any particular class 
activities too long.

\subsubsection{Meta-cognitive: Dynamic Self- and Class-assessment}

Both teachers accepted their role as orchestra conductors in the class. They had to assess not only themselves (self-assessment), but also the general class atmosphere at every time. It occurred that the class was fed up with some teacher-student interaction or some students had grasped the points while others were still puzzled. Clearly, teachers were responsible to assess the general atmosphere of the class and based on that decide on the most appropriate course of action.

In the second observation conducted in one of the classes of Vardak, teacher's meta-cognition was clearly challenged. It was observed that only a fraction of class-mostly volunteer students-actively participated in the class activities. Apparently, other students preferred to passively follow the class routines. Realizing the problem in this way, the teacher turned to other silent students and through asking questions tried to challenge their understanding and involve them in the class.

As understood from the above observation, meta-cognitive strategies had a regulatory function both for the teacher through conscious and continuous assessment of the self and for the class by keeping an eye over the whole of teaching and learning activities and taking appropriate measures in the most suitable time and place.

Concluding this section, it can be claimed that strategic behavior is a significant stage in any teacher professional development program. Operating in the risky field of ESP teaching, novice teachers can effectively draw on the strategies developed by those who are experienced in the practice. The above-mentioned categories of strategies along with two others- left unmentioned- can be considered under the same rationale.

\section{Conclusions and Implications}

ESP in Iran and many other ESL/EFL contexts is a novel area. The status quo shows that 'tradition' rules the field. Consequently, many important aspects including ESP teacher education have been left untouched scientifically. The common practice is that graduates of English departments embark on their career as novice ESP practitioners while they seek to find their way to the profession in a quite individual manner. Therefore, to clear the foggy angles of ESP teacher development and show the "how" of the practice, the present study drew on the experiences of two ESP professionals in a university where English was taught for petroleum-related majors. Four major guidelines emerged from the data were discussed to illustrate their rationale and applicability in the ESP class.

However, although local, cultural and educational policies affect the way teachers behave in the class, findings of the present study as involved the teachers' cognitions and practices in response to the similar structure of ESP classes can be suggested as useful guidelines for the ESP novice teachers to help them act and decide in the most useful way in the class.

As a shortcoming to the present study, it was conducted on a small scale and making any broad generalization to other contexts may not be warranted. However, it is hoped that it might have some implications for ESP teacher development in the context it was carried out and may be more widely. Also broad guidelines offered by the present study encourage more future research to investigate other unexplored aspects of ESP teaching and teacher development.

\section{Acknowledgements}

The authors are grateful to two experienced ESP teachers at PUT Ahwaz faculty-Mr. Sha'ban Vardak and Mr. Mohsen Pourghaffar- who participated in this study.

\section{References}

Asbaugh, C., \& Kasten, K. (1995). Educational leadership: Case studies for reflective practice. In Jackson, J. (1998), Reality-based decision cases in ESP teacher education: Windows on practice. English for Specific Purposes, 17, 2, 151-167. http://dx.doi.org/10.1016/S0889-4906(97)00004-5

Belcher, D. D. (2006). English for specific purposes: Teaching to perceived needs and imagined futures in worlds of work, study, and everyday life. TESOL Quarterly, 40,133-156

Bolam, R. (1993). Recent developments and emerging issues. In GTC Trust (Ed.), The continuing professional development of teachers. London: GTC Trust.

Chen, T. (2000). Self-training for ESP through action research. English for Specific Purposes, 19, 389-402. http://dx.doi.org/10.1016/S0889-4906(00)00008-9

Cooper, J. (1995). Teachers' problem solving: A casebook of award-winning teaching cases. In Jackson, J. (1998), Reality-based decision cases in ESP teacher education: Windows on practice. English for specific purposes, 17, 2, 


\section{1-167. http://dx.doi.org/10.1016/S0889-4906(97)00004-5}

Cossom, J. (1991). Teaching from cases: Education for critical thinking. Journal of Teaching in Social Work, 5, 139-155. http://dx.doi.org/10.1300/J067v05n01_11

Doyle, W. (1990). Case methods in the education of teachers. Teacher Education Quarterly, 17, 7-15

Dudley-Evans, T., \& St. John, M. J. (1998). Developments in ESP: A multi-disciplinary approach. Cambridge: Cambridge University Press.

Easton, G. (1982). Learning from case studies. New York: Prentice Hall.

Eleonora, V. R. (2003). Teacher professional development: An international review of the literature. Paris: UNESCO - International Institute for Educational Planning.

Elliott, J. (1991). Action research for educational change. In T.Chen (2000), Self-training for ESP through action research. English for Specific Purposes, 19, 389-402

Feiman-Neimser. (1990). Teacher preparation: structural and conceptual alternatives. In W. R. Houston (Ed.), Handbook of Research on Teacher Education. New York: Macmillan. pp. 212-290

Ferguson, G. (1997). Teacher education and LSP: The role of specialized knowledge. In R. Howard, \& J. Brown (Eds.), Teacher education for LSP. Clevedon, UK: Multilingual Matters. pp. 80-89

Furlong, J., \& Maynard, T. (1995). Mentoring student teachers: The growth of professional knowledge. In V. Griffiths, (2000), The Reflective dimension in teacher education. International Journal of Educational research, 33, $539-555$

Glatthorn, A. (1995). Teacher development. In Anderson, L. (2nd Ed.), International Encyclopedia of Teaching and Teachers Education. London: Pergamon Press.

Harding, K. (2007). English for specific purposes. Oxford: Oxford University Press.

Horsley, S. L. (1996). A definition of professional development. [Online] Available: http://teech.terc.edu/lectures/lectures/louckshorsely_def_nsta96.htm (August 2, 2006)

Huberman, M. (2001). Networks that alter teaching: Conceptualizations, exchanges and experiments. In J. Soler, A. Craft, \& H. Burgess (Ed.), Teacher Development: Exploring our own Practice. London: Paul Chapman Publishing and the Open University.

Hutchings, P. (1995). Notes on good cases. Paper presented at a Working Conference for College Faculty, "Improving teaching and learning through reflective practice" sponsored by the American Association of Higher Education (AAHE) Teaching Initiative and the Pace University Center for Case Studies in Education, University of British Columbia, Canada.

Hutchings, P. (1993). Using cases to improve college teaching: A guide to more reflective practice. Washington, D. C.: American Association for Higher Education.

Hutchinson, T., \& Waters, A. (1990). English for specific purposes: A learning-centered approach. Cambridge: Cambridge University Press.

Hutchinson, T., \& Waters, A. (1987). English for specific purposes: A learning-centered approach. Cambridge: Cambridge University Press. http://dx.doi.org/10.1017/CBO9780511733031

Jackson, J. (1998). Reality-based decision cases in ESP teacher education: Windows on practice. English for Specific Purposes, 17, 2, 151-167. http://dx.doi.org/10.1016/S0889-4906(97)00004-5

Jackson, J. (1996a). Cases in ESP teacher education: Preparing for unfamiliar discourse communities. Paper presented at the American Association of Applied Linguistics conference in Chicago, Illinois, USA in March.

Jackson, J. (1996b). Empowering practitioners: The case method in ESP teacher education. Paper presented at the TESOL convention in Chicago, Illinois, USA in March.

Jackson, J. (1995). Integrating language and content: EAP teacher education. Paper presented at the TESOL convention in Long Beach, CA, USA in March.

Jackson, J. (1994). From ESL to EAP: Teacher preparation for success. Paper presented at the MEXTESOL conference in Ixtapa, Mexico in October.

Kleinfeld, J. (1992). Learning to think like a teacher: The study of cases. In J. Shulman (Ed.), Case methods in teacher education. New York: Teachers College Press. 
Kleinfeld, J. (1991). Changes in problem solving abilities of students taught through case methods. Paper presented at the Annual Meeting of the American Educational Research Association, Chicago, IL, April 3-7, 1991

Koh, M.Y. (1988). The changing role of the ESL teacher and its implications for ESP. In M. Tickoo (Ed.), ESP: State of the art. Anthology Series, 21, 74-79

Maclean, J. (1997). Professional participation: A technique for LSP teacher education. In R. Howard, \& G. Brown, Teacher education for LSP. Clevedon: Multilingual Matters Ltd. pp. 158-175

Merriam, S.B. (1998). Qualitative research and case study applications in education. In O. Mahfoodh, \& A. Pandian (2011), A qualitative case study of EFL students' affective reactions to and perceptions of their teachers' written feedback. English Language Teaching, 4, 1-12. http://dx.doi.org/10.5539/elt.v4n3p14

Merseth, K., \& Lacey, C. (1993). Weaving stronger fabric: The pedagogical promise of hypermedia and case methods in teacher education. Teacher and Teacher Education, 9(30), 283-299. http://dx.doi.org/10.1016/0742-051X(93)90044-H

Merseth, K. (1991a). The case for cases in teacher education. Washington, DC: American Association of Higher Education and the American Association of Colleges for Teacher Education.

Merseth, K. (1991b). The early history of case-based instruction: Insights for teacher education today. Journal of TeacherEducation, 42, 243-249. http://dx.doi.org/10.1177/002248719104200402

Merseth, K. (1990). The case for cases. In Jackson, J. (1998), Reality-based decision cases in ESP teacher education: Windows on practice. English for Specific Purposes, 17, 2, 151-167. http://dx.doi.org/10.1016/S0889-4906(97)00004-5

Orr, T. (1996). Including an ESP component in ESL teacher training programs. Colloquium paper presented at the TESOL convention, Chicago, Illinois, US, March.

Richards, J. (1991). Reflective teaching in TESOL teacher education. In E. Sadtono (Ed.), Issues in language teacher education, 30, 1-19

Richards, J., \& Lockhart, C. (1994). Reflective teaching in second language classrooms. Cambridge: Cambridge University Press. http://dx.doi.org/10.1017/CBO9780511667169

Robinson, P. (1991). ESP today: a practitioner's guide. Hertfordshire, U. K.: Prentice Hall International (U. K.) Ltd.

Schon, D. (1987). Educating the reflective teacher. In Griffiths, V. (2000), The Reflective dimension in teacher education. International Journal of Educational research, 33, 539-555

Schon, D. (1983). The reflective teacher: How professionals think in action. New York: Basic Books.

Singh, G., \& Richards, J. C. (2006). Teaching and learning in language teacher course room: A critical socio-cultural perspective. RELC journal, 37, 149-175

Swales, J. M., \& L'Estrange, H. (1983). ESP administration and ESP teacher training. ESP Journal, 2, 87-100

Varnosfadrani, A. D. (2009). Teaching English for specific purposes. In Reinelt, R. (Ed.), Into the Next Decade with (2nd) FL Teaching. Rudolf Reinelt Research Laboratory EU Matsuyama, Japan. pp. 181-201

Wassermann, S. (1994a). Using cases to study teaching. Phi Delta Kappan, 75(8), 602-611

Wassermann, S. (1994b). Introduction to case method teaching: A guide to the galaxy. New York: Teachers College Press.

Waters, A. (1994). ESP things fall apart. In R. Khoo (Ed.), LSP" Problems and prospects. Singapore: SEAMEO Regional English Language Centre. pp. 1-14

Weaver, R., Kowalski, T., \& Pfaller, J. (1994). Case-method teaching. In K. Pilchard, \& R. McLaran Sawyer, (Eds.), Handbook of college teaching: theory and applications. Westport, CT: Greenwood Press. pp. 71-178

Wu, H., \& Badger, R. G. (2009). In a strange and uncharted land: ESP teachers' strategies for dealing with unpredicted problems in subject knowledge during class. English for Specific Purposes, 28, 19-32 
Table 1. ESP teachers who participated in the study

\begin{tabular}{lcccc}
\hline Teacher & Teacher experience (years) & ESP teaching experience & Degree & $\begin{array}{r}\text { ESP pre-service/ } \\
\text { In-service training }\end{array}$ \\
\hline Vardak & 28 & 27 & MA (ELT) & No \\
Pourghaffar & 27 & 25 & MA (ELT) & No \\
\hline
\end{tabular}

Table 2. Sample interview items

\begin{tabular}{|c|c|}
\hline 1. Initial preparation & $\begin{array}{l}\text { Any ESP formal or informal preparation at the beginning of the profession; } \\
\text { Entering the course as a General English teacher or already competent in } \\
\text { petroleum program }\end{array}$ \\
\hline $\begin{array}{l}\text { 2. Curricular } \\
\text { Pedagogical }\end{array}$ & $\begin{array}{l}\text { Engaging in an ESP petroleum curriculum development project with } \\
\text { colleagues who have conflicting ideas about what language skills should be } \\
\text { emphasized and preparing authentic ESP modular materials with limited } \\
\text { resources; } \\
\text { Deciding on an appropriate book for students in different petroleum-related } \\
\text { majors }\end{array}$ \\
\hline 3. Classroom Management & $\begin{array}{l}\text { Teaching in particular physical and cultural environment; } \\
\text { Introducing group work in the class; } \\
\text { Teacher-student clashes in case of limited content knowledge of the teacher }\end{array}$ \\
\hline $\begin{array}{l}\text { 4. Administrative } \\
\text { Personnel }\end{array}$ & $\begin{array}{l}\text { Interacting with content teachers and administrators; } \\
\text { Dealing with faculty administrators/advisors' expectations about what can be } \\
\text { accomplished in an ESP course; } \\
\text { Coping with the concerns of accountability }\end{array}$ \\
\hline
\end{tabular}

Table 3. Strategies along with subcategories

\begin{tabular}{|l|l|l|l|l|}
\hline Behavioral & Cognitive & Meta-cognitive & Teaching-related & Social \\
\hline $\begin{array}{l}\text { Risk-taking } \\
\text { strategies }\end{array}$ & $\begin{array}{l}\text { Use of pedagogic } \\
\text { aids (technical } \\
\text { dictionaries) }\end{array}$ & $\begin{array}{l}\text { Assessing self } \\
\text { and situations in } \\
\text { the class }\end{array}$ & $\begin{array}{l}\text { Knowledge of } \\
\text { lurriculum and } \\
\text { the hierarchies of } \\
\text { decisions in the } \\
\text { Department }\end{array}$ & $\begin{array}{l}\text { Setting rapport with } \\
\text { students }\end{array}$ \\
\hline $\begin{array}{l}\text { Being } \\
\text { energetic and } \\
\text { active in the } \\
\text { class }\end{array}$ & $\begin{array}{l}\text { Setting timelines } \\
\text { (managing the } \\
\text { time in the most } \\
\text { suitable way) }\end{array}$ & $\begin{array}{l}\text { Planning } \\
\text { strategies }\end{array}$ & $\begin{array}{l}\text { ESP curriculum } \\
\text { development }\end{array}$ & $\begin{array}{l}\text { Consulting with subject } \\
\text { knowledge instructors }\end{array}$ \\
\hline $\begin{array}{l}\text { Taking a a } \\
\text { positive } \\
\text { attitude to } \\
\text { teaching ESP }\end{array}$ & $\begin{array}{l}\text { Setting } \\
\text { reasonable } \\
\text { expectations of } \\
\text { him/herself }\end{array}$ & $\begin{array}{l}\text { Monitoring } \\
\text { strategies(taking } \\
\text { anticipatory } \\
\text { actions in the } \\
\text { class) }\end{array}$ & $\begin{array}{l}\text { Collaborative } \\
\text { teaching and } \\
\text { learning }\end{array}$ & $\begin{array}{l}\text { Self-motivation } \\
\text { strategies } \\
\text { income, employment in } \\
\text { Petroleum-company...) }\end{array}$ \\
\hline
\end{tabular}

